\title{
The stable performance of partial nitrification with the high salinity waste-brine
}

\author{
Jia-Chun Yang ${ }^{1,2}$ \\ ${ }^{1}$ Shenhua Group Corporation Limited, \\ Beijing, China, 100011 \\ ${ }^{2}$ Chinese Research Academy of Environmental Sciences, \\ Beijing, China, 100012 \\ E-mail: yangjia6722@163.com \\ Hui Ma and Yuan-Xiang Mao \\ School of chemical and environmental engineering, \\ China University of Mining \& Technology, \\ Beijing, China, 100083 \\ E-mail: mahui-472741887@qq.com
}

\begin{abstract}
Partial nitrification (PN) treatments on waste-brine were carried out in this study. Stable PN performance was obtained during continuous operation for 752 days, with a maximum nitrogen loading rate (NLR) of $3 \mathrm{~kg}^{-\mathrm{N}} \mathrm{m}^{-3} \mathrm{day}^{-1}$ and ammonium conversion rate (ACR) of $1.4 \mathrm{kgNm}^{-3} \mathrm{day}^{-1}$. The ratios of $\mathrm{NO}_{2}^{-}-\mathrm{N} /\left(\mathrm{NO}_{2}^{-}-\mathrm{N}^{-} \mathrm{NO}_{3}^{-}{ }^{-} \mathrm{N}\right)(\mathrm{NR})$ were always above $97 \%$, and BOD removal efficiencies were also stable at around $70 \%$ even if a sharp increase in NLR was applied during the stable period. Additionally, bacterial consortia analysis showed ammonium-oxidizing bacteria were the dominant microorganisms, which provided evidence for the long-term stable performance of this PN reactor. During the experiment, sludge setting properties deteriorated due to the absence of a biomass carrier. The stable performance of partial nitrification from waste-brine demonstrated the feasibility of the operation strategy in this study.
\end{abstract}

Keywords: Anammox, Brine, Nitrogen Removal, Partial Nitrification, Salinity.

\section{Introduction}

The natural gas and iodine, which are valuable natural resource, are produced from underground brine. The brine contains methane, iodine, and ammonium. After recovery of methane and iodine from this brine water, the remaining water (waste-brine) also contains high concentration of ammonium. It is important to note that the salinity of waste-brine was almost as high as seawater. Recently, nitrogen pollution has become a major concern in environment protection and increasing efforts have been directed at improving and discovering techniques for reducing the amount of nitrogen in wastewater [1]. Historically, sequential 
nitrification and heterotrophic denitrification have typically been applied for nitrogen removal, as well as the removal of organic matter, from waste water. Because this treatment approach involves huge amounts of energy and chemical costs, development of a cost-effective and economical ammonium removal processes is required. A novel and promising biological process of anaerobic ammonia oxidation (Anammox) provides an alternative to traditional processes [2].

$$
\begin{gathered}
\mathrm{NH}_{4}{ }^{+}+1.31 \mathrm{NO}_{2}{ }^{-}+0.066 \mathrm{HCO}_{3}{ }^{-}+0.13 \mathrm{H}^{+} \\
\rightarrow \mathrm{N}_{2}+0.26 \mathrm{NO}_{3}{ }^{-}+0.066 \mathrm{CH}_{2} \mathrm{O}_{0.5} \mathrm{~N}_{0.15}+2 \mathrm{H}_{2} \mathrm{O}
\end{gathered}
$$

Partial nitrification can produce a suitable influent to an anammox reactor for $\mathrm{NH}_{4}-\mathrm{N}$ removal from waste-brine. Thus, partial nitrification of ammonium to nitrite is the principal factor for successful application of a shortcut nitrogenremoval system in combination with the anammox process [3].

In this study, the treatment performance of a PN reactor which was operated for 752 days was evaluated and the effect of free ammonia (FA) and free nitrous acid (FNA) were also investigated. Microscope observation and DNA analysis were applied to evaluate the characteristics of sludge and the bacteria shift in our reactor.

\section{Materials and Methods}

\subsection{Experimental setup and operational strategy}

The experiment was carried out in a laboratory-scale rectangular reactor with an effective volume of $5 \mathrm{~L}$ (Figure 1). The cross-sectional areas of the downdraft and updraft parts of the reactor were $110 \times 110 \mathrm{~mm}$ and $110 \times 30 \mathrm{~mm}$, respectively, and the height of effluent port was $320 \mathrm{~mm}$ (total volume $6.2 \mathrm{~L}$ ). A settling tank with volume of $2.5 \mathrm{~L}$ was used for sludge sedimentation and recycling. The air flow rate was changed along with increments in the nitrogen loading rate (NLR). Temperature was maintained at $26 \pm 4^{\circ} \mathrm{C}$ throughout the study and $\mathrm{pH}$ was controlled at $7.6 \pm 0.1$ by addition of acid $(1 \mathrm{~N} \mathrm{HCl})$ and alkali $(1 \mathrm{~N} \mathrm{NaOH})$ solution. The dominant bacterial species in the consortium was identified as the Anammox bacterium KU2, and the initial MLSS was $4500 \mathrm{mg} \mathrm{L}^{-1}$. The reactor was fed with the TN concentration of $180-200 \mathrm{mg} \mathrm{L}^{-1}$. 


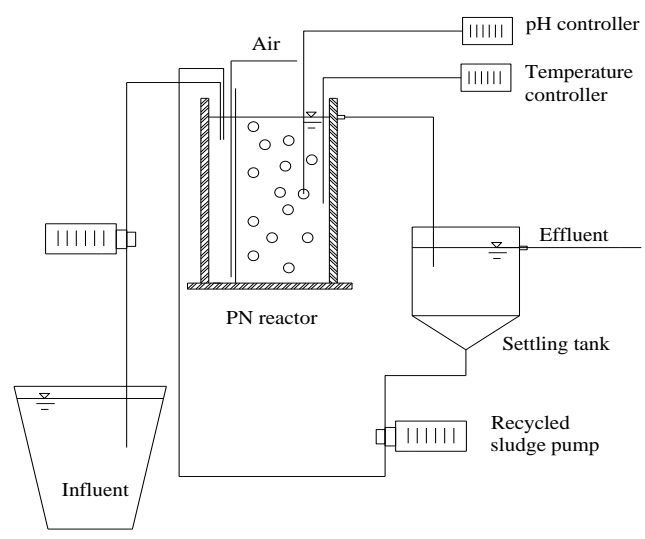

Fig. 1. Schematic of the PN reactor

\subsection{Analytical methods}

The influent and effluent samples were analyzed immediately or stored in the refrigerator at $4{ }^{\circ} \mathrm{C}$ until the analyses were carried out. $\mathrm{NH}_{4}{ }^{+}$-N was analyzed by the modified phonate method using o-phenyl phenol (OPP) (Kanda, 1995). $\mathrm{NO}^{2-}$ $\mathrm{N}$ and nitrite $\left(\mathrm{NO}_{3}^{-}-\mathrm{N}\right)$ were measured using a colorimetric method. The $\mathrm{pH}$ and DO values were determined using a $\mathrm{pH}$ meter (B-211, Horiba, Kyoto, Japan) and a DO meter (D-55, Horiba, Kyoto, Japan), respectively. MLSS analysis was performed by drying the samples at $105^{\circ} \mathrm{C}$ in an evaporating dish.

(1) SEM observation

The surface and inner parts of the Anammox granules were observed using scanning electron microscope (SEM). Samples were first washed in a $0.1 \mathrm{M}$ phosphate buffer solution ( $\mathrm{pH}$ 7.4) for $5 \mathrm{~min}$. The samples were then hardened for $90 \mathrm{~min}$ in a $2.5 \%$ glutaraldehyde solution prepared with the phosphate buffer solution. Next, samples were washed in the buffer solution three times for 10 min each and fixed for $90 \mathrm{~min}$ in a $1.0 \%$ OsO4 solution prepared using the phosphate buffer solution. After washing samples three times for 10 min each in the buffer solution, they were dewatered for $10 \mathrm{~min}$ each in serially graded solutions of ethanol at concentrations of 10, 30, 50, 70, 90 and 95\%. SEM observations were conducted using a scanning electron microscope (JEOL, JSM-5310LV, and Japan).

(2) DNA analysis

DNA extraction and Polymerase Chain Reaction (PCR) amplification

The granular sludge sample was ground with a pestle under liquid nitrogen. Meta-genom DNA was extracted using an ISOIL kit (Wako, Osaka, Japan) in accordance with the manufacturer's instructions. Amplification of the 16S rRNA gene was performed with Phusion High-Fidelity DNA polymerase (Finnzymes, 
Espoo, Finland) using conserved eubacterial primers 6F (forward primer: 5'GGAGAGTTAGATCTTGGCTCAG-3') (Tchelet, 1999) and 1492r (reverse primer: 5'-GGTTACCTTGTTACGACT-3') (Lane, 1991). PCR was carried out using the following thermo cycling parameters: $30 \mathrm{~s}$ initial denaturation at $98^{\circ} \mathrm{C}$, 25 cycles of $10 \mathrm{~s}$ at $98^{\circ} \mathrm{C}, 30 \mathrm{~s}$ at $51{ }^{\circ} \mathrm{C}$, and $20 \mathrm{~s}$ at $72{ }^{\circ} \mathrm{C}$, and $5 \mathrm{~min}$ final elongation at $72{ }^{\circ} \mathrm{C}$. The amplified products were electrophoresed on a $1 \%$ agarose gel, and the excided fragments were purified using Wizard SV Gel and PCR Clean-Up System (Promega, Madison, WI, USA).

\section{Results and Discussion}

\subsection{The stable performance of the $P N$ reactor}

The operational parameters and treatment results are summarized in Table 1. Figure 2 shows the daily changes in NLR and AOR. table PN performance was obtained during continuous operation from day552-752, with a maximum nitrogen loading rate (NLR) of $4.2 \mathrm{kgN} \mathrm{m}^{-3} \mathrm{day}^{-1}$ and ammonium oxidation ratio (AOR) of $2.1 \mathrm{kgNm}^{-3} \mathrm{day}^{-1}$.

Table 1. The performance of the PN reactor under various operational conditions

\begin{tabular}{llll}
\hline \hline Items & Period I & Period II & Period III \\
\hline Time (d) & $0-226$ & $226-552$ & $552-752$ \\
HRT (h) & 24 & 3 & 4.2 \\
NLR & $0.05-1.5$ & & \\
InfluentTN (mg/L) & $180-200$ & $180-200$ & $150-200$ \\
$\begin{array}{l}\text { EffluentTN (mg/L) } \\
\text { Sludge } \\
\text { concentration(mg- }\end{array}$ & $60-130$ & $0-150$ & $50-150$ \\
MLSS/L) & $4500-17900$ & 9000 & 32000 \\
\hline \hline
\end{tabular}

(1) Period I

During this period I (0-226 days), the reactor was operated to cultivate ammonia-oxidizing bacteria (AOB) and to inhibit nitrite-oxidizing bacteria (NOB). Initially, the reactor was started at a low NLR of $0.05 \mathrm{kgNm}^{-3} \mathrm{day}^{-1}$ (200 $\mathrm{mg} / \mathrm{L}$ of $\mathrm{NH}_{4}{ }^{-} \mathrm{N}$ ), with a hydraulic retention time (HRT) of $24 \mathrm{~h}$. Air was supplied to the reactor at a flow rate of $0.2 \mathrm{~L} / \mathrm{min}$ for controlling the reactor DO concentration to inhibit $\mathrm{NO}_{3}{ }^{-}-\mathrm{N}$ production. Effluent $\mathrm{NH}_{4}{ }^{-} \mathrm{N}$ and $\mathrm{NO}_{3}{ }^{-} \mathrm{N}$ concentrations were decreased gradually in the $\mathrm{PN}$ reactor which demonstrated the occurrence of nitrification as well as the inhibition of NOB in the reactor. 

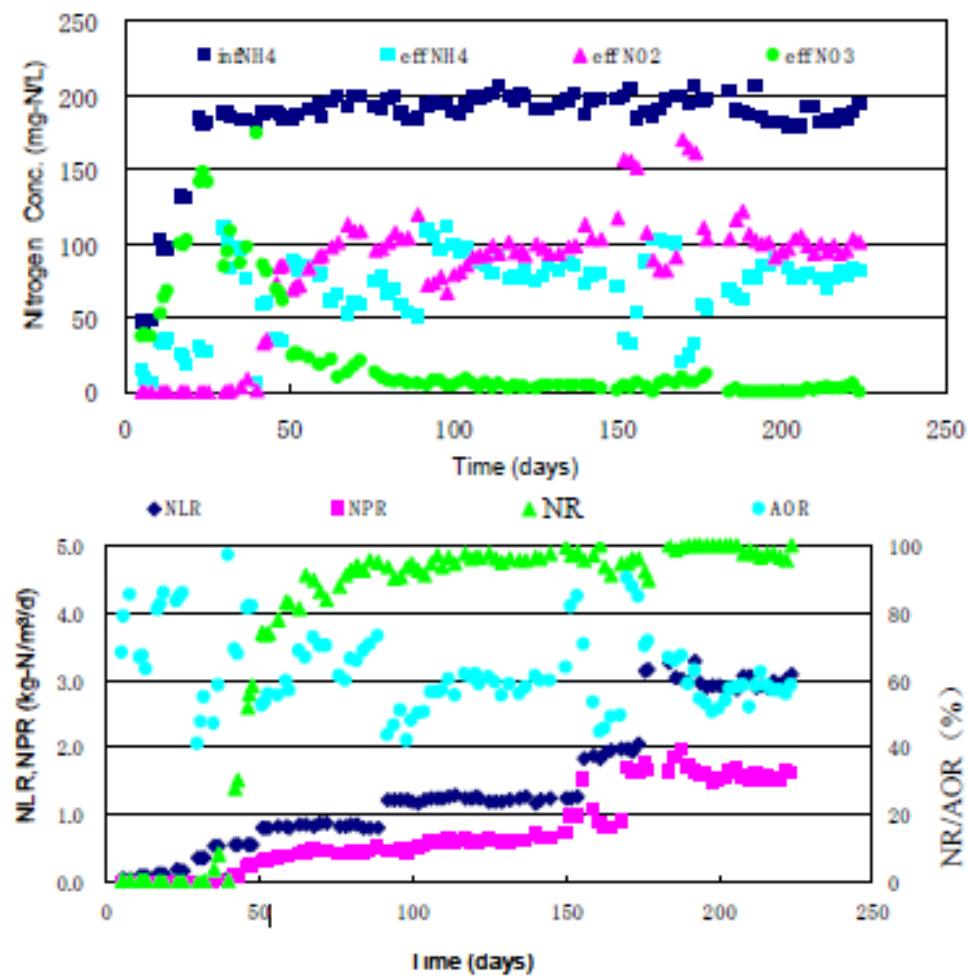

Fig. 2. Changes in total Influent NH4-N, effluent NH4-N NO2--N, NLR (TNLR) and AOR. (Period I)

\section{(3) Period II}

From day 226 to day 552, the influent $\mathrm{NH}_{4}{ }^{-} \mathrm{N}$ concentration was not changed and HRT was shortened to increase the NLR. The residual DO concentration in the reactor was under $0.1 \mathrm{mg} / \mathrm{L}$. Varied operational conditions was adopted to check the stable performance. From day 276, the waste-brine was adopted as the substitution for synthetic wastewater. Negative effects were appeared in the first 100 running day. Also, the maximum NLR of $2.5 \mathrm{kgNm}^{-}$ ${ }^{3} \mathrm{day}^{-1}$ was obtained. The average effluent $\mathrm{NO}^{2-\mathrm{N}} /\left(\mathrm{NO}_{2}{ }^{-}-\mathrm{N}+\mathrm{NO}_{3}{ }^{-}-\mathrm{N}\right)$ ratio was always more than $99 \%$. 


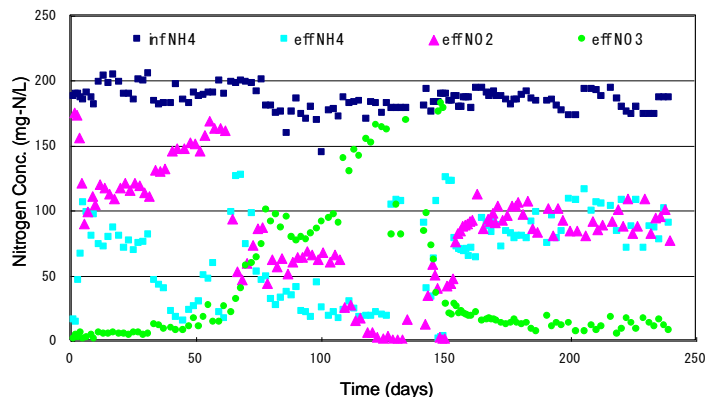

Fig. 3. Changes in total Influent NH4-N, effluent NH4-N NO2-N, NLR (TNLR) and AOR. (Period II)

Anthonisen et al. observed that inhibition of NOB began at a concentration of 0.1-1.0 mg-FA/L, while AOB became inhibited at 10-150 mg-FA/L[4]. The NOB growth can be selectively inhibited in a range of FNA of approximately 0.011-0.10 mg $\mathrm{HNO}_{2}$-N/L.As shown in Figure 4, we confirm the fact that the production of $\mathrm{NO}_{3}{ }^{-}-\mathrm{N}$ was decreased as well as the $\mathrm{pH}$ was higher than 7 . The inhibition on $\mathrm{AOB}$ growth started at approximately $0.20 \mathrm{mg} \mathrm{HNO}_{2}-\mathrm{N} / \mathrm{L}$ and completely stopped at $0.60 \mathrm{mg} \mathrm{HNO}_{2}-\mathrm{N} / \mathrm{L}$, while the inhibition on NOB growth started at approximately $0.021 \mathrm{mg} \mathrm{HNO}_{2}-\mathrm{N} / \mathrm{L}$ and completely stopped at approximately $0.033 \mathrm{mg} \mathrm{HNO}_{2}-\mathrm{N} / \mathrm{L}$

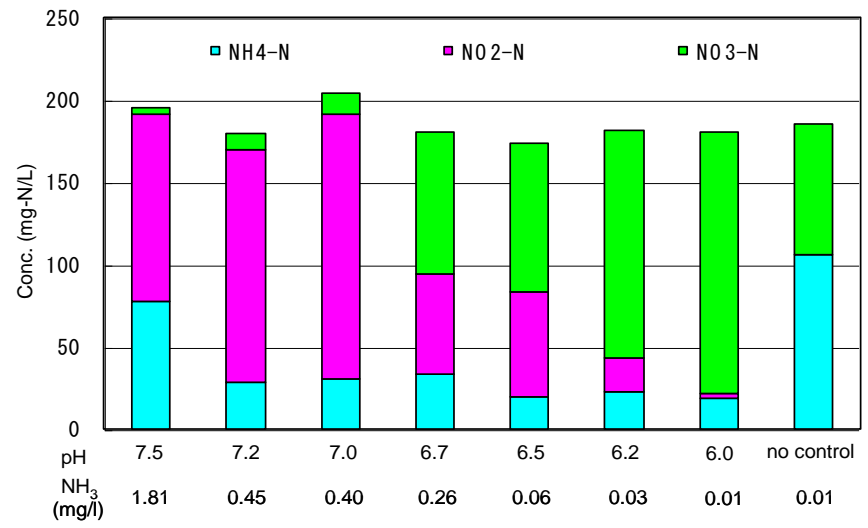

Fig. 4. The production of NH4-N, NO2-N and NO3-N under different $\mathrm{pH}$.

\section{(3) Period III}

After obtaining satisfactory $\mathrm{PN}$ treatment results for the subsequent Anammox reactor, the influent flow rates and $\mathrm{TN}$ concentration were simultaneously adjusted to get the suitable ratio of $\mathrm{NO}_{2}^{-}-\mathrm{N} / \mathrm{NH}_{4}-\mathrm{N}$. A maximum NLR of $3 \mathrm{kgN} \mathrm{m}^{-3} \mathrm{day}^{-1}$ and the stable NPR of $1.4 \mathrm{kgN} \mathrm{m}^{-3} \mathrm{day}^{-1}$ were achieved on day 600 with an influent $\mathrm{NH}_{4}^{-} \mathrm{N}$ concentration of $200 \mathrm{mg} / \mathrm{L}$. The DO 
concentrations in the reactor were maintained near to $0 \mathrm{mg} / \mathrm{L}$ in this period. A stable effluent $\mathrm{NO}_{2}{ }^{-}-\mathrm{N} / \mathrm{NH}_{4}-\mathrm{N}$ ratio of $1.1 \pm 0.2$ was also steadily maintained which was suitable for the subsequent Anammox process.

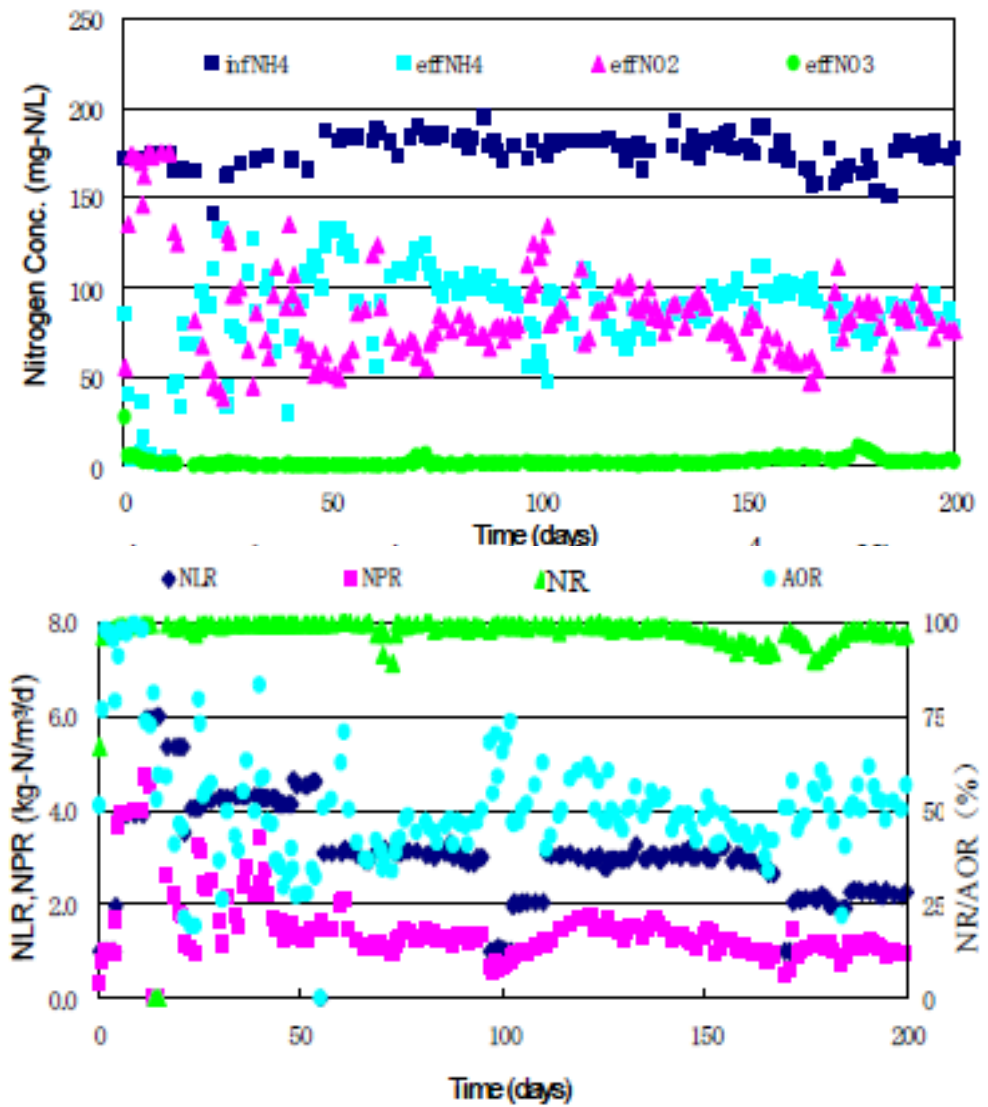

Fig. 5. Changes in total influent NH4-N, effluent NH4-N, NO2-N, NLR (TNLR) and AOR. (Period III)

The work of Vadivelu et al. indicates that nitrite oxidation could be selectively inhibited by FNA [5]. The inhibition on AOB growth started at approximately $0.10 \mathrm{mg} \mathrm{HNO}_{2}-\mathrm{N} / \mathrm{L}$ and completely stopped at $0.40 \mathrm{mg} \mathrm{HNO}_{2}-$ $\mathrm{N} / \mathrm{L}$, while the inhibition on NOB growth started at approximately $0.011 \mathrm{mg}$ $\mathrm{HNO}_{2}-\mathrm{N} / \mathrm{L}$ and completely stopped at approximately $0.023 \mathrm{mg} \mathrm{HNO}-\mathrm{N} / \mathrm{L}$. This indicates that the NOB growth can be selectively inhibited in a range of FNA of approximately $0.011-0.10 \mathrm{mg} \mathrm{HNO}_{2}-\mathrm{N} / \mathrm{L}$. Compared with the low DO concentration in this reactor, the FNA concentration was considered as the main factor to inhibit NOB activity except for the startup period. Therefore, it is essential to control FA and FNA within the appropriate range during operation. 
In this study, the control of FA and FNA was also regarded as the operational strategy. This study researched the time courses of FA and FNA concentrations during the entire experimental period (Figure 6).

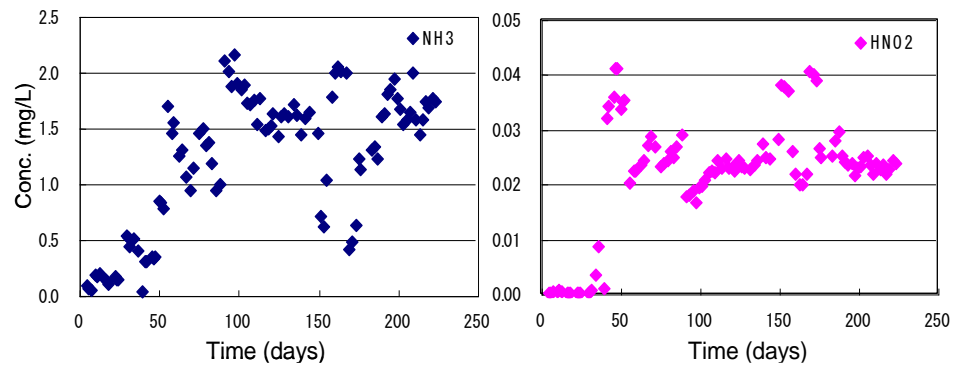

Fig. 6. Time courses of FA and FNA concentrations during experimental period.

As shown in Figure 6, during the first 100 days, the FA and FNA concentrations fluctuated, accompanied with significant changes in the ACR. In the successive operational period, ACR was stable and the FA and FNA concentrations were approximately $1.5-2.0 \mathrm{mg} / \mathrm{L}$ and $0.02-0.03 \mathrm{mg} / \mathrm{L}$, respectively. The accumulation of $\mathrm{NO}_{3}^{-}-\mathrm{N}$ was negligible, indicating that aerobic ammonium oxidizing reactions were dominant, due to the successful control of FA and FNA, in accordance with the findings by Anthonisen et al.

\subsection{Sludge characteristics of $P N$ reactor}

The morphology and size distribution of the sludge taken from the PN reactor on the 180 day are shown in Figure 7 (a) to (b). As the experiment progressed, there were decreasing trends in sludge size and frequency, which may be due to the absence of a biomass carrier in the PN reactor. The collision and friction among particles would be strengthened without the buffering function of the biomass carrier. Consequently, the sludge diameter tended to decrease progressively.
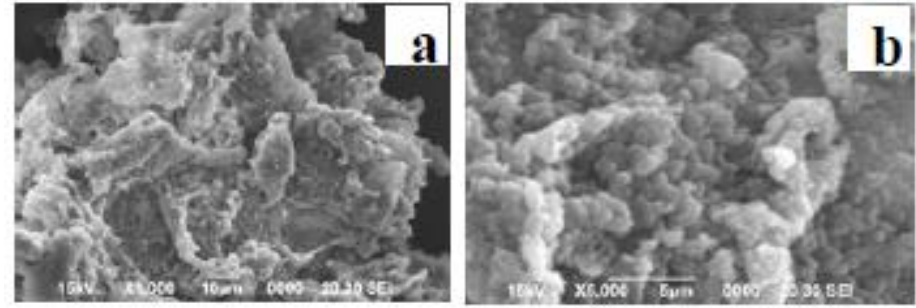

Fig. 7. The sludge morphology and size taken from the PN reactor on the 180 day.

Table 2 shows the results of inorganic components analysis of sludge 167 day. Fe and $\mathrm{Si}$ in the inorganic components were accounted for more than $60 \%$, but $\mathrm{P}, \mathrm{Ca}, \mathrm{Na}, \mathrm{Al}, \mathrm{Mg}, \mathrm{K}, \mathrm{S}$ were accounted for less than $40 \%$. In the brine, iron 
concentration was $2.5 \mathrm{mg} / \mathrm{L}$ which was 10 times of the iron in seawater. Therefore, iron was the most occupied in the PN sludge.

Table 2. The Composition of the PN sludge

\begin{tabular}{cccc}
\hline $\begin{array}{c}\text { inorganic } \\
\text { component }\end{array}$ & $\begin{array}{c}\text { ratio } \\
(\text { wt \%) }\end{array}$ & $\begin{array}{c}\text { inorganic } \\
\text { component }\end{array}$ & $\begin{array}{c}\text { ratio } \\
(\text { wt \%) }\end{array}$ \\
\hline $\mathrm{Fe}$ & 39.81 & $\mathrm{Si}$ & 22.98 \\
$\mathrm{P}$ & 8.42 & $\mathrm{Ca}$ & 7.34 \\
$\mathrm{Na}$ & 5.63 & $\mathrm{Al}$ & 5.02 \\
$\mathrm{Mg}$ & 3.24 & $\mathrm{~K}$ & 3.19 \\
$\mathrm{~S}$ & 2.80 & & \\
\hline
\end{tabular}

The initial sludge volume index (SVI) value of the sludge was $123 \mathrm{~mL} / \mathrm{g}$, and then decreased to $62.7 \mathrm{~mL} / \mathrm{g}$ after 110 days of operation, which indicated the improvement of sludge settling properties. The low SVI value was concluded to be due to the increase in sludge density, as nitrifiers often form cell aggregates in enrichment cultures. However, an obvious increase in SVI value occurred from the 150th day on, with a maximum value as high as $162 \mathrm{~mL} / \mathrm{g}$ on day 184 , causing abundant sludge accumulation in the settling tank. This phenomenon was attributed to either of two reasons. One is the absence of a biomass carrier. it reported that the attachment and detachment motion of biofringe carriers can improve the settling ability of sludge[6]. The other possibility is nitrogen overload, which arose from the sharp increase of influent substrate concentration and flow rate. High NLR evidently needed higher aeration to support sufficient dissolved oxygen for ammonium oxidation, which may have resulted in excessive turbulence in the system [7].

An improvement in the settling characteristics was achieved by using biofringe material as a biomass carrier in the reactor. The swimming motion enhances detachment of excess biomass, which causes formation of a dense sludge floc [8-9]. Thus, sludge with good settling characteristics was formed. The SVI value decreased gradually to $80 \mathrm{~mL} / \mathrm{g}$, while MLSS decreased concurrently, which indicates an increase in attached sludge on the biofringe material.

\subsection{DNA analysis}

After long-term operation, adaptation could either lead to the acclimation of the existing bacterial population to the new conditions or a significant shift in the microbial community, so the changes in the bacterial populations were monitored. Biomass samples were taken from the reactor on day 37 and day 89 and analyzed for the presence of nitrifying bacteria and the composition of the microbial community. As listed in Table 3, during the steady operational phase, DNA analysis showed that almost bacteria hybridized with Parvularcula sp.CC- 
MMS-1 distributed throughout the biofilm, namely most of bacteria were consisted of Parvularcula sp. CC-MMS-1 positive beta-subclass ammoniumoxidizing bacteria (micrographs are not shown). However, for the sample on day 89 after long terms of running of reactor, the DNA analysis clearly showed that the dominant bacteria were unclearly.

The explanation for these findings is that the bacterial established a new equilibrium in the population, leading to the uniform distribution of bacterial population.

In this way, the nitrite oxidizers, existing in the oxygen-limited reactor, were eliminated under high FA concentration condition for the further potential steady operation of partial nitrification process. Actually the acclimation of the bacteria to the operational conditions might be a problem since FA influence might be reduced significantly after long time for the acclimatization of biomass. However, this phenomenon did not significantly appear in this study, which could be interpreted as absolutely change of bacteria populations. In the high ammonium conditions, the most expected microbial group, representing mostly by members of the AOB and holding a critical role in the reactor, was developed and could be more potential for partial nitrification in this reactor. 
Table 3. The DNA analysis of bacteria taken from PN sludge of day 37 and day 89

\begin{tabular}{|c|c|c|c|c|c|}
\hline \multirow[b]{2}{*}{ Taxon } & \multirow[b]{2}{*}{ Accession } & \multicolumn{2}{|c|}{ day 37} & \multicolumn{2}{|c|}{ day 89} \\
\hline & & \begin{tabular}{|c}
$\begin{array}{c}\text { Identity } \\
(\%)\end{array}$ \\
\end{tabular} & $\begin{array}{c}\text { Number of } \\
\text { clones }\end{array}$ & $\begin{array}{c}\text { Identity } \\
(\%)\end{array}$ & $\begin{array}{c}\text { Number of } \\
\text { clones }\end{array}$ \\
\hline Uncultured bacterium clone SS-57 & AY945873 & $92-93$ & & 93 & \\
\hline Parvularcula sp. CC-MMS-1 & EU346850 & $91-92$ & $14 / 76$ & 92 & $4 / 27$ \\
\hline Uncultured alpha proteobacterium clone F1_08f & EF123358 & $91-92$ & & 92 & \\
\hline Uncultured bacterium clone Np77 & AM295541 & 98 & & 98 & \\
\hline Nitrospira marina & X82559 & 98 & $8 / 76$ & 98 & $1 / 27$ \\
\hline Nitrospira marina strain $\mathrm{Nb}-295$ & $\underline{\mathrm{L} 35501}$ & $9 \underline{6}$ & & $\underline{96}$ & \\
\hline 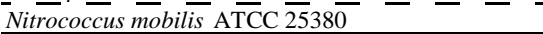 & $\overline{\mathrm{L}} 355 \overline{10}$ & $9 \overline{7}$ & $1 \overline{76}$ & $\overline{97}$ & $1 / 27$ \\
\hline Nitrosococcus oceani ATCC 19707 & CP000127 & 99 & & 99 & \\
\hline Nitrosococcus oceani strain $\mathrm{AFC} 27$ & AY 690336 & 99 & & 99 & \\
\hline$\overline{\text { Nitrosomonas }}$ sp. $\overline{\mathrm{ls}} 425-$ & $\overline{\mathrm{AJ}} 62 \overline{1029}$ & 99 & & $99 \overline{-100}$ & \\
\hline Nitrosococcus mobilis $\mathrm{Nc} 2$ & AF287297 & 99 & 2710 & $98-100$ & \\
\hline Uncultured Roseovarius sp. clone B217 & EU360291 & 96 & & & \\
\hline Roseobacter sp. 812 & DQ120726 & 96 & 7176 & - & - \\
\hline Roseovarius tolerans strain Ekho Lake-172 & Y11551 & $95-96$ & $1 / 10$ & - & - \\
\hline Iodide-oxidizing bacterium SE-1 _ _ & $\mathrm{AB} 159209$ & -95-96 & & & \\
\hline 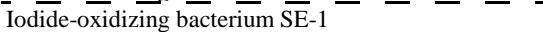 & $\overline{\mathrm{AB}} 15 \overline{92} 09$ & $97 \overline{-98}$ & & & \\
\hline Iodide-oxidizing bacterium RB-2A & AB159203 & $96-97$ & $3 / 76$ & - & - \\
\hline Uncultured Roseobacter 253-13 & AJ294351 & -96-97 & & & \\
\hline 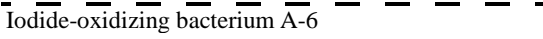 & $\overline{\mathrm{AB}} 15 \overline{92} 00$ & $9 \overline{9}$ & & - & - \\
\hline Roseovarius sp. 2 S5-2 & $\mathrm{AB} 114 \underline{422}$ & 99 & $1 /$ & - & \\
\hline Uncultured Roseobacter sp. clone $\overline{\mathrm{DE}} \overline{4.1}$ & $\mathrm{~A} \overline{\mathrm{Y}} 588 \overline{89} 49$ & 94 & $1 \overline{76}$ & - & - \\
\hline Iodide-oxidizing bacterium WAI-2 & AB159208 & 90 & $3 / 76$ & - & - \\
\hline Iodide-oxidizing bacterium Q-1 & AB159207 & 90 & $3 / / 0$ & & \\
\hline Uncultured gamma proteobacterium clone MKC19 & EF173350 & 96 & 6176 & 96 & $3 / 2$ \\
\hline Lysobacter taiwanensis strain CL-1358 & 4555 & 95 & $0 / 10$ & $95-96$ & $3 / 2$ \\
\hline Uncultured gamma proteobacterium clone C-CS3 & AY622233 & 98 & $2 / 76$ & - & \\
\hline Rhodanobacter spathiphylli type strain: B39 & AM087226 & 97 & $2 / 16$ & - & \\
\hline Rhodanobacter spathiphylli type strain: B39 & $\mathrm{A} \overline{\mathrm{M}} 08 \overline{72} 26$ & $9 \overline{4}$ & $1 \overline{76}$ & $\overline{-}$ & - \\
\hline Roseovarius aestuarii strain SMK-122 & EU156066 & 97 & $1 / 76$ & 97 & $2 / 27$ \\
\hline Marinobacter sp. NK-1 & AB026946 & 98 & $1 / 76$ & 98 & $1 / 27$ \\
\hline Rubrimonas cliftonensis strain:0Ch317 & D85834 & 94 & $5 / 76$ & _- & - \\
\hline Uncultured alpha proteobacterium clone SM1C11 & AF445668 & 93 & & & \\
\hline Uncultured soil bacterium clone PK_V & EF540436 & 96 & $3 / 76$ & - & \\
\hline Rhodobacter sphaeroides ATCC 17029 & CP000578. & $\underline{95}$ & & & \\
\hline Rhodobacter vinaykumaraii strain JAJA2 $24 \overline{9}$ & $\mathrm{~A} \overline{\mathrm{M}} 60 \overline{06} 42$ & $9 \overline{5}$ & $1 \overline{76}$ & $\overline{-}$ & $\overline{-}$ \\
\hline $\begin{array}{l}\text { Pseudomonas pseudoalcaligenes } \text { strain: } 14 \\
\end{array}$ & AB276371 & 99 & $1 / 76$ & 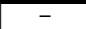 & $\overline{-}$ \\
\hline Arenibacter latericius KMM 426T & AF052742 & 97 & $1 / 76$ & - & $\overline{-}$ \\
\hline Alteromonas sp. D & AB004313 & 95 & $1 / 76$ & - & - \\
\hline Sinorhizobium sp. NH-14 & EF486317 & 95 & $1 / 76$ & - & - \\
\hline Uncultured Alcanivorax sp. clone XJ40 & EF648121 & 94 & $1 / 76$ & - & - \\
\hline Colwellia sp. BSi20045 & DQ060391 & 94 & $1 / 76$ & - & - \\
\hline Uncultured bacterium clone WLB16-200 & DQ015862 & 97 & $1 / 76$ & - & - \\
\hline Uncultured bacterium clone $\mathrm{MKC} 25$ & EF173356 & 98 & $1 / 76$ & - & - \\
\hline Uncultured bacterium clone ELB19-216 & DQ015834 & 96 & 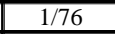 & 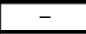 & $\overline{-1}$ \\
\hline Uncultured alpha proteobacterium clone GuBH2-AG- & AJ519653 & 94 & $1 / 76$ & 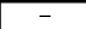 & $\overline{-1}$ \\
\hline Uncultured bacterium clone 21B42 & DQ925896 & 91 & $1 / 76$ & - & 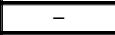 \\
\hline Uncultured Rhodobacteraceae bacterium isolate EG7 & AM691097 & 88 & $1 / 76$ & - & - \\
\hline Uncultured bacterium clone Asc-s-95 & EF632661 & - & - & 99 & $2 / 27$ \\
\hline
\end{tabular}

\section{Conclusion}

In this study, we showed that the anammox process is reliable at the salinity of $30 \mathrm{~g} / \mathrm{L}$. A maximum nitrogen loading rate (NLR) of $3 \mathrm{kgN} \mathrm{m}^{-3} \mathrm{day}^{-1}$ and 
ammonium conversion rate(ACR) of $1.4 \mathrm{kgNm}^{-3} \mathrm{day}^{-1}$. According to the DNA analysis results, during the steady operational phase, DNA analysis showed that almost bacteria hybridizedwith Parvularculasp. CC-MMS-1 distributed throughout the biofilm. It was also confirmed in this study that the sludge settling properties of the sludge could be effectively improved by using the biofringe material as a biomass carrier.

\section{References}

1. Mulder, A., Astrid, A., van de Graaf, et al. Anaerobic ammonium oxidation discovered in a denitrifying fluidized reactor [J]. FEMS Microbiol. Ecol.1995, 16: pp177-184.

2. Furukawa. K., Inatomi, Y., Qiao, S., et al. Innovative treatment system for digester liquor using anammox process [J]. Bioresour. Technol. 2009, 100: pp5437-5443.

3. Fux, C., Boehler, M., Huber, P., Brunner, I., Siegrist, and H: Biological treatment of ammonium-rich wastewater by partial nitrification and subsequent anaerobic ammonium oxidation (anammox) in a pilot plant. J. Biotechnology. 2002, 99: pp295-306.

4. Anthonisen, A.C., Loehr, R.C., Prakasam,T.B. et al. Inhibition of nitrification by ammonia and nitrous acid [J]. J. Water Pollut. Control. Fed. 1976, 48: pp835-852.

5. Vadivelu. V. M., Keller J, Yuan. Z. G. Effect of free ammonia on the respiration and growth processes of an enriched nitrobacter culture [J]. Wat. Res. 2007, 41: pp826-834.

6. Tokutomi, T. Operation of a nitrite-type airlift reactor at low DO concentration [J]. Water Sci. Technol. 2004, 49, pp: 81-88.G.H. Weiss (ed.), Contemporary Problems in Statistical Physics (SIAM, Philadelphia, 1994).

7. Kanda, J. Determination of ammonium in seawater based on the indophenol reaction with -phenyl phenol (opp) [J]. Wat. Res. 1995, 29: pp2746-2750.

8. Prinčič, A., Mahne, I., Megušar, F., Paul, E.A., Tiedje, J.M.Effects of pH and oxygen and ammonium concentrations on the community structure of nitrifying bacteria from wastewater[J].Applied and Environmental Microbiology. 1998, 64: pp3584-3590.

9. Wiesmann, U., Biological nitrogen removal from waste water [J]. In: Foechter, A. (Ed.), Advances in Biochemistry and Engineering/ Biotechnology. 1994, 51: pp113-154. 